\title{
Electrode Performance of Vanadium Pentoxide Xerogel Prepared by Microwave Irradiation as an Active Cathode Material for Rechargeable Magnesium Batteries \\ Masashi INAMOTO, ${ }^{a}, *$ Hideki KURIHARA, $^{a}$ and Tatsuhiko YAJIMA ${ }^{b}$
}

a Saitama Industrial Technology Center, 3-12-18 Kamiaoki, Kawaguchi-shi, Saitama 333-0844, Japan

b Saitama Institute of Technology, 1690 Fusaiji, Fukaya-shi, Saitama 369-0293, Japan

* Corresponding author: inamoto-m@saitec.pref.saitama.jp

\begin{abstract}
Vanadium pentoxide xerogel was prepared by irradiation with microwaves and successfully applied as the active cathode material of a magnesium rechargeable battery. The structure and electrochemical properties of the $\mathrm{V}_{2} \mathrm{O}_{5}$ xerogel were investigated and compared with $\mathrm{V}_{2} \mathrm{O}_{5}$ prepared by conventional heat-treatment. X-ray diffraction revealed that the $\mathrm{V}_{2} \mathrm{O}_{5}$ xerogel prepared by $\mathrm{MW}$ irradiation has low crystalline structure. Charge-discharge tests revealed a specific capacity of $463 \mathrm{mAh} \mathrm{g}^{-1}$, which was much larger than of $\mathrm{V}_{2} \mathrm{O}_{5}$ prepared by conventional heattreatment (190 $\left.\mathrm{mAh} \mathrm{g}^{-1}\right)$.
\end{abstract}

(C) The Electrochemical Society of Japan, All rights reserved.

Keywords : Rechargeable Magnesium Battery, Vanadium Pentoxide, Xerogel, Microwave

\section{Introduction}

Magnesium rechargeable batteries, which have been studied for a long time, have begun to draw attention for next generation power storage applications. Magnesium is a low-cost material, safe to handle, environmentally-friendly and naturally abundant.

However, there have been a limited number of materials available as the cathode for magnesium rechargeable batteries. Aurbach et al. reported an electrolyte solution that allowed $\mathrm{Mg}$ to dissolve and deposit reversibly. ${ }^{1,2}$ Novak et al. reported $\mathrm{V}_{2} \mathrm{O}_{5}$ to be a candidate cathode material. ${ }^{3,4}$ Imamura et al. reported $\mathrm{Mg}^{2+}$ intercalation into a composite prepared from a $\mathrm{V}_{2} \mathrm{O}_{5}$ xerogel and carbon. They reported that the $\mathrm{V}_{2} \mathrm{O}_{5}$ /carbon composite has a large interlayer distance and short diffusion length compared to the $\mathrm{V}_{2} \mathrm{O}_{5}$ xerogel without carbon. ${ }^{5}$ In this study, we focus attention on the drying process of the $\mathrm{V}_{2} \mathrm{O}_{5}$ xerogel, which is known to develop a narrow interlayer distance by thermal drying over $50^{\circ} \mathrm{C} .{ }^{5}$ Microwave (MW) irradiation under vacuum was employed to dry the $\mathrm{V}_{2} \mathrm{O}_{5}$ xerogel in an attempt to achieve a longer interlayer distance than that prepared by conventional heat-treatment.

\section{Experimental}

$\mathrm{V}_{2} \mathrm{O}_{5}$ xerogel was prepared by a sol-gel process. $\mathrm{V}_{2} \mathrm{O}_{5}(1 \mathrm{~g})$ was added to $10 \mathrm{wt} \% \mathrm{H}_{2} \mathrm{O}_{2}$ aqueous solution $(100 \mathrm{~mL})$ under electromagnetic stirring. The hydrogel was dried overnight to produce a dark brown xerogel of $\mathrm{V}_{2} \mathrm{O}_{5}$. The $\mathrm{V}_{2} \mathrm{O}_{5}$ xerogel was placed in a glass vessel and irradiated with MWs $(500 \mathrm{~W}, 2.45 \mathrm{GHz})$ for $4 \mathrm{~min}$ under vacuum. For comparison, $\mathrm{V}_{2} \mathrm{O}_{5}$ xerogels were dried at 200 and $300^{\circ} \mathrm{C}$ for $8 \mathrm{~h}$. The structure of the $\mathrm{V}_{2} \mathrm{O}_{5}$ xerogel was examined by X-ray diffraction (XRD; Rigaku, RINT 2000).

Electrodes were prepared using a 7:2:1 weight-ratio mixture of $\mathrm{V}_{2} \mathrm{O}_{5}$ xerogel, acetylene black and polyvinylidene fluoride (PVDF) binder in N-methyl-2-pyrrolidone solvent, and spreading the resulting slurry $\left(5 \mathrm{mg} \mathrm{cm}^{-2}\right)$ on carbon paper. The electrode was dried at $110^{\circ} \mathrm{C}$ for $1.5 \mathrm{~h}$. Cyclic voltammetry $(\mathrm{CV})$ was measured for the three-electrode cells using an electrochemical measurement system (Hokuto Denko, HZ-3000) with $\mathrm{Ag} / \mathrm{AgCl}$ as the reference electrode. The electrode charged with magnesium ions was used as a counter electrode. As a counter electrode, that is, $\mathrm{S}-\mathrm{V}_{2} \mathrm{O}_{5}$ prepared by our method $^{6}$ was charged with magnesium ions and used as a counter electrode. This electrode shows the same potential changes as a magnesium alloy plate. Magnesium alloy plate was used as the reference electrode. Thus, electrode performance was evaluated using three-electrode cells. $0.3 \mathrm{M} \mathrm{Mg}\left(\mathrm{ClO}_{4}\right)_{2}$ dissolved in propylene carbonate (PC) was used as the electrolytic solution. Chargedischarge tests were conducted between cut-off potentials of 0.9 and $2.4 \mathrm{~V}$ (vs. $\mathrm{Mg} / \mathrm{Mg}^{2+}$ ) at a constant current of $60 \mathrm{~mA} \mathrm{~g}^{-1}$ ( $0.1 \mathrm{C}$ rate). All three-electrode cells set up in a nitrogen atmosphere and they were closed container. All measurements were conducted at room temperature $\left(25^{\circ} \mathrm{C}\right)$.

\section{Results and Discussion}

Figure 1 shows XRD patterns of the $\mathrm{V}_{2} \mathrm{O}_{5}$ products. The $\mathrm{V}_{2} \mathrm{O}_{5}$ xerogel dried at $300^{\circ} \mathrm{C}$ for $8 \mathrm{~h}$ (Fig. 1c) was generally equivalent to that of crystalline $\mathrm{V}_{2} \mathrm{O}_{5}$. These results are similar to those reported by Hibino et al. ${ }^{7}$ In contrast, XRD profiles of the $\mathrm{V}_{2} \mathrm{O}_{5}$ xerogel irradiated with MWs for $4 \mathrm{~min}$ (Fig. 1a) and that dried at $200^{\circ} \mathrm{C}$ for $8 \mathrm{~h}$ (Fig. 1b), both of which had a broad and strong diffraction peak around $2 \theta=7$ and broad and weak peaks around $2 \theta=23$ and $31^{\circ}$, which indicate structurally-preserved xerogel. ${ }^{8}$ These peaks was

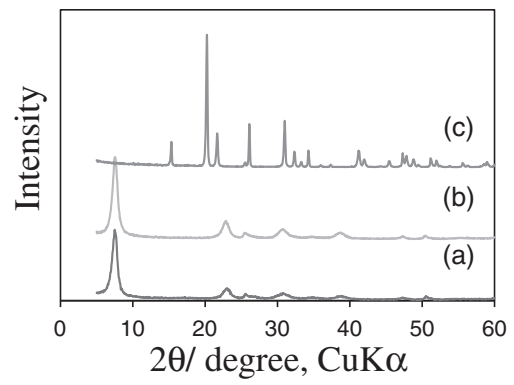

Figure 1. XRD patterns of vanadium pentoxides prepared by (a) MW irradiation for $4 \mathrm{~min}$, (b) heat-treatment at $200^{\circ} \mathrm{C}$ for $8 \mathrm{~h}$, and (c) at $300^{\circ} \mathrm{C}$ for $8 \mathrm{~h}$. 


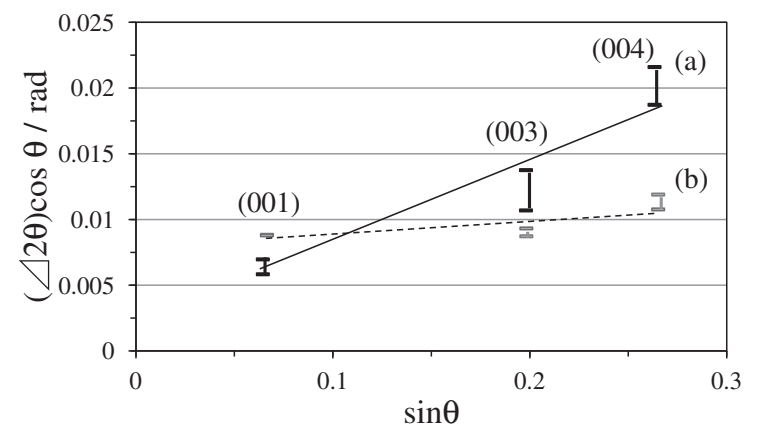

Figure 2. Williamson-Hall plots of $\mathrm{V}_{2} \mathrm{O}_{5}$ prepared by (a) $\mathrm{MW}$ irradiation and (b) heat-treatment at $200^{\circ} \mathrm{C}$. The vertical width of the plot represents a deviation.

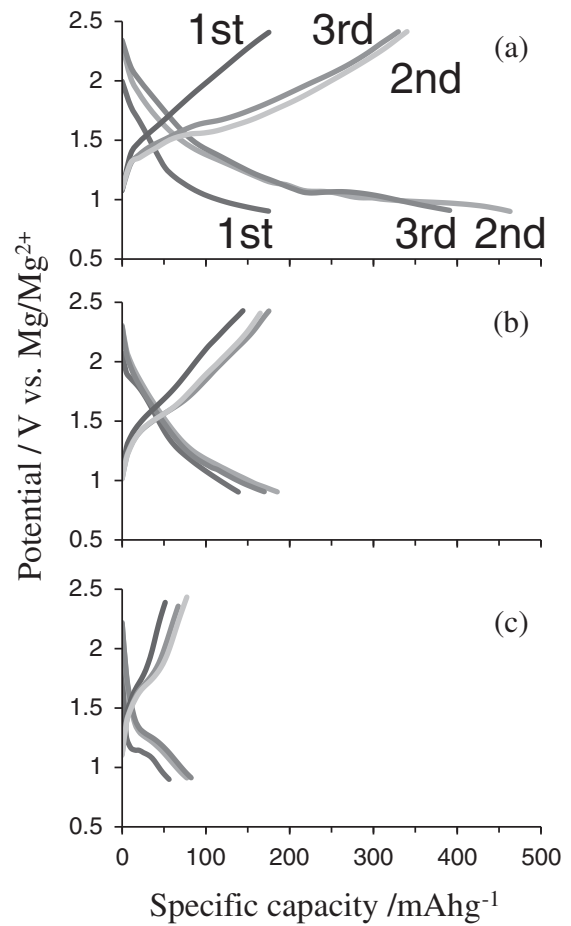

Figure 3. Charge-discharge curves of $\mathrm{V}_{2} \mathrm{O}_{5}$ prepared by (a) $\mathrm{MW}$ irradiation, (b) at $200^{\circ} \mathrm{C}$, and by (c) heat-treatment at $300^{\circ} \mathrm{C}$.

(001), (003) and (004) face. The peak intensity of the MW irradiated $\mathrm{V}_{2} \mathrm{O}_{5}$ was lower than that of the heat-treated $\mathrm{V}_{2} \mathrm{O}_{5}$, and the diffraction peaks of the former were shifted to lower angles, which indicates that MW irradiation results in lower crystallinity and longer interlayer distances than conventional heat-treatment, because MW selectively heats only water molecules in the xerogel. The interlayer distance was calculated by using the Bragg equation. Prepared by MW irradiation $(\mathrm{d}=11.96 \AA)$ was longer than by heattreatment $(\mathrm{d}=11.58 \AA)$. Williamson-Hall plots of the XRD peaks are shown in Fig. 2. The slope of $\mathrm{V}_{2} \mathrm{O}_{5}$ prepared by $\mathrm{MW}$ irradiation is more inclined than that prepared by conventional heat-treatment, which indicates that the crystal structures of $\mathrm{V}_{2} \mathrm{O}_{5}$ prepared by MW irradiation is characterized by distorted layers. Therefore, it is considered that hydrate waters are instantaneously eliminated by MW irradiation.

Charge and discharge capacity curves are shown in Fig. 3. The capacity of crystalline $\mathrm{V}_{2} \mathrm{O}_{5}$ was $77 \mathrm{mAh}^{-1}$ (Fig. 3c), which is similar to that reported by $\mathrm{Yu}$ et al. ${ }^{10}$ The first discharge capacity of $\mathrm{V}_{2} \mathrm{O}_{5}$ prepared by heat-treatment at $200^{\circ} \mathrm{C}$ was $138 \mathrm{mAhg}^{-1}$

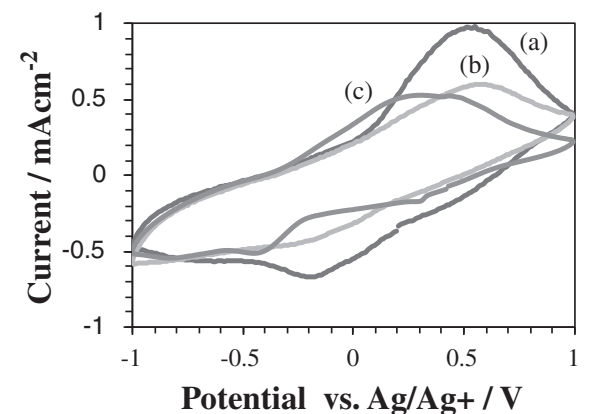

Figure 4. Cyclic voltammograms $\left(1 \mathrm{mV} \mathrm{s}^{-1}\right.$, 2nd cycle) of $\mathrm{V}_{2} \mathrm{O}_{5}$ prepared by (a) $\mathrm{MW}$ irradiation, (b) heat-treatment at $200^{\circ} \mathrm{C}$ and (c) heat-treatment at $300^{\circ} \mathrm{C}$.

(Fig. 3b). The second discharge capacity was comparable with the first. In contrast, the first discharge capacity of $\mathrm{V}_{2} \mathrm{O}_{5}$ prepared by MW irradiation was $175 \mathrm{mAh} \mathrm{g}^{-1}$ (Fig. 3a) and the second discharge capacity was increased 2.66 times, which indicates that $\mathrm{Mg}^{2+}$ insertion increased after the first cycle. The second discharge capacity was $463 \mathrm{mAh} \mathrm{g}^{-1}$. These results may be considered that the surface became enlivened as electrode of nickel-hydride battery and the interlayer distance was increased by the first-cycle insertion of $\mathrm{Mg}^{2+}$ ions. Theoretical capacity of $\mathrm{V}_{2} \mathrm{O}_{5}$ xerogel was $483 \mathrm{mAh} \mathrm{g}^{-1}$. It is indicated that interlayer distance of $\mathrm{V}_{2} \mathrm{O}_{5}$ prepared by $\mathrm{MW}$ irradiation is similar in long to $\mathrm{V}_{2} \mathrm{O}_{5}$ xerogel.

Figure 4 shows cyclic voltammograms for the prepared xerogels. $\mathrm{V}_{2} \mathrm{O}_{5}$ prepared by $\mathrm{MW}$ irradiation had a cathodic peak around $-0.15 \mathrm{~V}$ vs. $\mathrm{Ag} / \mathrm{Ag}^{+}$, and the cathodic response started in the early stage compared with that for the heat-treated $\mathrm{V}_{2} \mathrm{O}_{5}$. These results indicate that $\mathrm{Mg}^{2+}$ ions inserted to interlayer of $\mathrm{V}_{2} \mathrm{O}_{5}$ and that $\mathrm{MW}$ irradiation increases $\mathrm{Mg}^{2+}$ insertion sites. In contrast, $\mathrm{V}_{2} \mathrm{O}_{5}$ prepared by conventional heat-treatment at $200^{\circ} \mathrm{C}$ did not display a same cathodic peak, because the interlayer distance was as short as that reported by Hibino et al. ${ }^{9}$ However, $\mathrm{V}_{2} \mathrm{O}_{5}$ prepared by heattreatment at $300^{\circ} \mathrm{C}$ had a cathodic peak around $-0.45 \mathrm{~V}$. This result may indicate that $\mathrm{Mg}^{2+}$ ions were inserted to around apical oxygen. ${ }^{11}$ Therefore, the CV results are consistent with the XRD and charge-discharge test results.

\section{Conclusions}

$\mathrm{V}_{2} \mathrm{O}_{5}$ xerogel prepared by MW irradiation had low crystallinity and distorted layers. The first cycle capacity was $175 \mathrm{mAh} \mathrm{g}^{-1}$, which is almost the same as $\mathrm{V}_{2} \mathrm{O}_{5}$ prepared by conventional heattreatment. However, the second discharge capacity of the former was $463 \mathrm{mAh} \mathrm{g}^{-1}$, which is 2.66 times larger than that of the latter.

\section{References}

1. D. Aurbach, Z. Lu, A. Schechater, Y. Gofer, R. Turgeman, Y. Cohen, M. Moshkovich, and E. Levi, Nature, 407, 724 (2000).

2. D. Aurbach, Y. Cohen, and M. Moshkovich, Electrochem. Solid-State Lett., 4, A113 (2001).

3. P. Novak and J. Desilvestro, J. Electrochem. Soc., 140, 140 (1993).

4. P. Novak, W. Scheifele, and O. Haas, J. Power Sources, 51, 479 (1995).

5. D. Imamura and M. Miyayama, Solid State Ionics, 161, 173 (2003).

6. M. Inamoto, H. Kurihara, and T. Yajima, Hyomen Gijutsu, 62, 516 (2011).

7. M. Hibino, Y. Ikeda, Y. Noguchi, and T. Kudo, Seisan Kenkyu, 52, 516 (2000).

8. I. Stojkovic, N. Cvjeticanin, S. Markovic, M. Mitric, and S. Mentus, Acta Physica Polonica A, 117, 837 (2010).

9. M. Hibino, Y. Ikeda, and T. Kudo, Seisan Kenkyu, 53(9-10), 432 (2001).

10. L. Yu and X. Zhang, Colloid Int. Sci., 278, 160 (2004).

11. M. Hibino and T. Kudo, Hyomen Gijutsu, 45, 36 (1998). 